Session 2171

\title{
Initiating a Program on Humanitarian Engineering: Rationale, Implementation, Problems, and Perceptions
}

\author{
Jean-Pierre Delplanque, Joan Gosink, and Juan Lucena \\ Division of Engineering \\ Division of Liberal Arts and International Studies \\ Colorado School of Mines, Golden, CO 80401
}

\begin{abstract}
With the support of a grant from the William and Flora Hewlett Foundation, faculty at the Colorado School of Mines (CSM) are initiating a new program in Humanitarian Engineering (http://humanitarian.mines.edu/). Our specific goals are to: create a culture of acceptance for humanitarian service endeavors among engineering students and faculty; increase the number of engineering graduates that enter occupations and /or internships in service related industries and organizations; and, increase the recruitment and retention of women and minority students. The project includes the development of a minor degree program in Humanitarian Engineering (HE). The minor degree involves extensive collaboration and participation of faculty from the Division of Liberal Arts and International Studies (LAIS) at CSM. First envisioned as a minor degree available only to students with civil, electrical, environmental and mechanical engineering, the concept has evoked widespread interest among students and faculty at CSM, resulting in the planning of a second minor degree in Humanitarian Studies and Technology, which would serve students in applied science and economics. In this paper, we present some of the problems and issues associated with this multidisciplinary endeavor, involving engineering, the sciences and the humanities.
\end{abstract}

\section{Introduction}

The 21st century has brought Americans a new awareness of anguish and discontent in lower income countries, and an emerging recognition of the need for U.S. participation to ameliorate this suffering. Attendant with these issues is the demand for enhanced security, safety, and equity for the disadvantaged. At the same time, engineering graduates shy away from political life, community service, and international work in the non-profit sector. ${ }^{4}$ Engineering talent is not making sufficient contributions toward the solutions of major human needs such as access to clean water, nutrition, as well as health and education facilities. It is also important to sustain both human systems and natural systems within an ethical framework which recognizes the disproportionate impact of engineering and applied science in contemporary society. ${ }^{9}$ Indeed the site for resource development is often within countries noted for autocratic or even dictatorial leadership where the public, and especially the poor have little impact on decisions related to land or water usage. 
Further, when it comes to engineering's relevance to the world's most challenging problems, the public attitude toward engineering is not very encouraging. ${ }^{9}$ 9Leaders in engineering education and the profession have argued that the perception that engineering is irrelevant to humanity's present and future needs may be a key reason for the steady decline of engineering enrollment over the last decade, as well as the persistent under-representation of women and minorities in engineering. Engineering students are too often misperceived to be more concerned with their personal vocational interests and material goals and uncaring about society at large, particularly the plight of the developing world. ${ }^{1,3,6-8}$ Arguably, the development of humanitarian engineering programs will enhance the role of the engineer in society, and, while not necessarily increase overall enrollments, will act as a magnet for excellent students, who might otherwise refrain from careers as engineers.

In order to address these issues, a project has been initiated at CSM to develop a new cadre of engineers, sensitive to social contexts, committed and qualified to serve humanity by contributing to the solution of complex problems at regional, national, and international levels and locations around the world in need of "smart" technical assistance. This goal will be achieved through the development, under the sponsorship of the William and Flora Hewlett Foundation, of a humanitarian Engineering component for CSM engineering curriculum that will teach engineering students how to bring technical knowledge and skill to bear on the real-world problems of the less materially advantaged. Examples of this might be creating and maintaining the infrastructure of disaster relief, designing low-tech water supply and treatment systems in developing countries, assisting with the creation of inexpensive housing opportunities for the poor, constructing schools or health clinics, designing and implementing sustainable ways to meet basic human needs for food and shelter, and to improve their quality of life in terms of energy, transportation, and communication. This new cadre of engineers may be employed by corporations, government agencies, or non-governmental organizations (NGOs). Their expertise will be balanced in terms of technical excellence, economic sagacity, ethical maturity, and cultural sensitivity. Humanitarian engineers will help corporations identify new ways to contribute to community development, promote more effective citizen service among government agencies, and assist NGOs in the creation of an transnational civil society. It is worth noting that we have already received an expression of interest from one mining company for graduates with these skills.

To accomplish this goal we are modifying existing courses and introducing new engineering courses that convey relevant knowledge and training for service missions. This curriculum consists of both technical and non-technical courses to develop the skills, expertise, understanding, and attitudes that support pro-active humanitarian engineering and community service.

The specific goals of the project include:

(1) Create a culture of acceptance and value of humanitarian engineering, community and international service activities at CSM. We anticipate that the first result of this project will be an enhanced appreciation of the value and importance of the participation of engineers in community and international service.

(2) Increase the number of CSM engineering graduates that enter occupations that have a community or international service emphasis. Although this is a long time goal, we anticipate measurable changes in employment patterns within three years. 
(3) Increase the recruitment of women and minority students to the engineering program at CSM. As a result of new recruitment activities that emphasize service and our K-12 outreach activities, we anticipate an increase in applications from women and minority students. ${ }^{5}$

(4) Increase the number of engineering students that enter internships in community or international service. As a result of the newly established agreements with sponsoring organizations such as the US Department of Health and Human Services, Engineers Without Borders, the Namlo Foundation, Golden Independent School, and the Federal University of Santa Maria in Brazil, we anticipate an increase in students participating in these endeavors. Furthermore, we plan to establish additional agreements with similar agencies during the course of the project.

\section{Program Implementation}

\subsection{Curriculum Development and Enhancements}

\section{Senior Design/Service Missions}

Senior design is a linchpin of the program, through which some students engage in design projects with international and community service emphases. In the past, senior design students at CSM have participated in various projects of this type. Some examples include: a ski chair for paraplegics, a small structure at a Salvation Army camp, and a page turning device for the handicapped. The HE program aims at significantly increasing the number, complexity and duration of the projects. With this expanded vision, we designate those senior design projects fulfilling this framework as service missions. We have already developed relationships with a number of international liaisons humanitarian engineering and community service organizations to promote service missions. Our goal is to motivate and challenge engineering students to find innovative and creative solutions to technical problems afflicting underprivileged communities worldwide. Since there are over 320 seniors in the Engineering Division at CSM, and each senior design project typically involves a team of four or five students, we offer about seventy or eighty projects each year. We anticipate that about ten of these projects will be designated as service missions. Of course, many, if not most students will fulfill their senior design requirement through traditional projects involving the design and manufacture of products or processes for local industries, or participation in national and regional design competitions.

At CSM, senior design projects are completed in two courses, EGGN 491 and 492, (http://egweb.mines.edu/eggn491/ and http://egweb.mines.edu/eggn492) consisting of four and three credits, respectively. Typically, students develop the design and plans for the project during the first semester (EGGN 491), and implement the project during the second (EGGN 492) semester. The time schedule for service missions is consistent with this schedule, since students may travel to remote sites during the Christmas or Spring breaks.

\section{Multidisciplinary Engineering Laboratories}

We are in the process of modifying our award winning Multi-disciplinary Engineering Laboratories (MEL) sequence, to provide students with new skills in engineering disciplines that have particular relevance to service missions. MEL will introduce experiments related to distributed energy systems (fuel cells, solar cells, wind turbines), sensors for monitoring well 
water levels and quality, and sensors for contaminant transport and containment. This knowledge and the associated technical skills will enable CSM engineering students to help people in remote communities improve their access to energy and power.

\section{Modifications to existing Engineering Courses}

In soil mechanics laboratory, civil engineering students will be introduced to sensor technologies for identifying and quantifying soil contaminant species and concentration using an EPA superfund contaminated soil site next to CSM campus along Clear Creek.

The Analog and Digital Communications Systems course will be modified to cover cellular and satellite communications systems particularly applicable to communications for remote and inaccessible communities. The Image and Multidimensional Signal Processing course will incorporate a new section on image processing for remote sensing, focusing on the utility of multi- and hyper-spectral sensor for agricultural and natural resource monitoring. The Introduction to Feedback Control Systems and the Microcomputer Architecture and Interfacing courses will incorporate a new set of projects focused on the humanitarian engineering and community service control applications such as power regulation in a windmill or a solar array, process control in a sewage treatment plant, or control of a pumping station for a community water supply.

\section{New engineering and technical courses}

We are planning to develop a variety of new courses with topics focusing on technical issues related to humanitarian engineering projects: small hydro; micro-turbine design; desalinization; photovoltaic systems; alternative energy; biomechanics for the disabled; groundwater and pollutant transport and remediation; low-cost medical imaging methods; small-scale communications systems; remote sensing as a tool in community planning, infrastructure planning, natural resource planning, environmental assessment, and disaster relief. We have begun a pro-active search for continued funding for the HE courses and program after termination of the Hewlett grant, and are optimistic of our fund-raising prospects. The CSM Office of Institutional Advancement is in full support of our efforts.

One possible approach being considered for the implementation of these courses is to package them as one-credit "applications" courses. This is an approach that we have tried within the framework of a grant from the NSF for reform of the engineering curriculum (NSF-EEC0230699). In this approach, a three-credit course is converted into two-credit/one-credit course combination, in which fundamentals are taught in the two-credit module, with applications taught in the follow-on one-credit module. Students would be required to enroll in the fundamental two-credit course and then select one or more one-credit course as follow-on.

\section{Humanities Coursework}

Students involved in humanitarian engineering also require knowledge of and skills in the ethical, cultural, and environmental dimensions of engineering practice related to the regional, national, and international setting where they will perform service work. In addition to technical topics, the humanitarian engineering program also features coursework related to the human factors associated with community and international service missions. For example, students

participating in service missions in third world countries, many of whom have never traveled outside Colorado, will be called upon to appreciate differences in cultural norms, especially 
those related to gender, age and religion. They will be faced with different expectations in terms of work ethics, etiquette, and political perspectives. Although it is optimistic to expect that a few courses ( a total of fifteen credit hours) will provide these students with the knowledge and diplomatic skills required of these endeavors, we believe that is essential to provide them with an understanding of relevant and significant cultural, political, historical factors. This coursework is being developed by the Division of Liberal Arts and International Studies at CSM (LAIS) and involves the development of new courses (such as a special section of the existing course on Nature and Human Values, tailored for engineers in humanitarian engineering.).

\section{Area of Special Interest and Minors}

Two minors and an area of special interest related to the Humanitarian engineering program are being developed jointly by the Division of Engineering and the Division of Liberal Arts and International Studies (LAIS). The following three options to be offered to CSM students are currently being considered for approval:

1. Area of Special Interest (ASI) in Humanitarian Studies $(12 \mathrm{cr})$ : focuses on the humanities aspects of the program. Further information regarding ASI programs at CSM can be found on the web site http://www.alumnifriends.mines.edu/viewbook/10_curriculum2.htm.

2. Minor in Humanitarian Studies and Technology (18 cr): Available to all undergraduate students at CSM.

3. Minor in Humanitarian Engineering $(28+\mathrm{cr})$ : extends the above minor to include multidisciplinary engineering labs, senior design and internships. Note that all students in the Engineering Division at CSM are required to take seven hours of senior design, and three hours of Multidisciplinary Engineering Laboratory (MEL). Thus this minor program contains only eighteen credits of "new" work. Furthermore, since all CSM students have nine hours of free electives, and at least two of the LAIS courses can be double counted, the minor can easily be completed in a standard four year program.

\subsection{Internships}

Internships, both regional and international, are being developed to become a major component of the training for Humanitarian Engineers. In these internships, American students may experience their first exposure to extreme poverty and different cultural perspectives. We understand that it is critically important to provide interns and students on service missions with an awareness of and sensitivity to these differences. For example, through discussions with community leaders in St. Kitts, we have ascertained that a low-tech water treatment system is preferable to one with sophisticated electronic controls and other modern features. ${ }^{2}$ Therefore the students are designing a system that meets the local preferences. Students will receive training regarding differences in cultural perspectives through the coursework associated with the Minor in Humanitarian Engineering. We are also following the advice of our experienced host organizations on these matters. Additional information will be generated during the course of the project by direct contact with sponsoring agencies and local governments. This knowledge will be accumulated in the form of handbooks and guidelines.

We are already focusing on the development of four elements that will ensure the long-term continuation of international and regional internships in humanitarian engineering. First, the creation of strong linkages with industry, government, and international and regional humanitarian and community service organizations will assure the continuation of the service 
mission component of the program after completion of the grant. For example, one of our faculty members is a member of the Board of Advisors of the organization, Engineers Without Borders, and this organization acts as a clearing house for identifying appropriate international projects for engineering groups. Second, the development of internship guidelines and handbooks will ensure that interns meet the learning and service objectives of the program, especially the objective that calls for continuously seeking and making explicit the relationship between engineering practice and humanitarian engineering. Students will be able to recognize this relationship, and hopefully act on it, later in their careers. Third, we will develop a training seminar and materials for internship advisors, who might come from CSM graduate students in International Political Economy and/or CSM faculty, to ensure that advisors provide students with high quality advising after the grant expires. Fourth, we will develop a handbook for host organizations to help them understand how to seek, recruit, and advise engineering interns beyond CSM. This will ensure that humanitarian and community service organizations build the capacity to host engineering interns beyond CSM and the life of the grant, thereby leveraging the effects of the Hewlett Foundation funding.

\section{Regional organizations}

The U.S. Department of Health and Human Services and the U.S. Public Health Service very recently established a memorandum of understanding with CSM. The U.S. Public Health Service provides opportunities for engineering students to work with mentors in that organization in the development of projects commensurate with the goals of the HE project. Through this agreement students will participate in internships and summer projects related to health and human services, occupational safety and health, testing of medical and household devices, and in projects associated with the Indian Health Service, Center for Disease Control and Prevention, and the National Institute for Occupational Safety and Health. Host organizations, such as the Indian Health Service, will provide students with information on cultural perspectives. This information, coupled with the non-technical coursework in the Humanitarian Engineering Minor program, will help students to assimilate regional values and preferences.

Another venue for humanitarian engineering internships and service missions is the Partnership for Public Service, a federal organization dedicated to revitalizing civil service in the US, particularly by educating and facilitating the placement of college students in internships with local, state, and federal community organizations. The most significant of these organizations is the Corporation for National and Community Service, which administers the Americorps and the Learn and Serve America programs. After 9/11 these federally funded programs have received a significant budget increase $(+40 \%)$, have also become part of the USA Freedom Corps which will extend their service reach abroad, and have the incredible challenge to recruit an additional 25,000 members $(+50 \%)$ for FY 2003. Hence, the demand for engineering interns and the financial resources will be available from an external source well beyond the life of this grant. Also, the availability of significant stipends and benefits with support from the Hewlett Foundation will make these programs attractive to our engineering students who are usually offered well-paid summer jobs in the private sector.

\section{International organizations}

CSM has a long tradition of international participation. Exchange agreements exist with more than fifty universities in Australia, South America, Europe and Asia (http://www.iie.org/pgms/global-e3/). However, these are primarily for semesters abroad. We 
envision internships and service missions to be of shorter duration. We are pursuing the development new agreements appropriate for service missions and internships. We have already established linkages with several organizations for this purpose. These organizations include the Federal University of Santa Maria (FUSM) in Brazil, Engineers Without Borders (EWB), and the Namlo Foundation (http://www.namlo.org) in Nepal to develop collaborative projects for senior design. Both Engineers Without Borders (http://www.ewb-usa.org/) and the Namlo Foundation are non-profit 501(c)(3) tax-exempt corporations created under the law of Colorado.

Quoting the web page (http://www.ewb-usa.org), "The mission of Engineers Without Borders ... is to help disadvantaged communities improve their quality of life through implementation of environmentally and economically sustainable engineering projects, while developing internationally responsible engineering students." The EWB-CSM chapter plans to pursue both international and domestic projects. EWB-CSM is involved with and recruiting from all levels of campus life. Freshmen and sophomores are being involved in domestic projects while upper class and graduate students will be involved in international projects. EWB-CSM students have already participated in a design/construction project in Belize Central America in 2003 and plan continued efforts early next year. This project involved the design/construction of a solar powered lighting system for the church, meeting hall, and women's health clinic in San Pablo, Belize. The students' designs were reviewed by chapter members with the advice of faculty members. Some possible destinations for future projects suggested by the EWB include Uzbekistan, Afghanistan, and Thailand. We are also trying to identify sites in the Southwest U.S., especially in Colorado and nearby New Mexico. EWB at Mines will provide social, technical, managerial, and entrepreneurial skills to students who want be involved in projects in these and other destinations.

All the humanitarian organizations with which we collaborate were identified quite easily, through the personal knowledge of CSM faculty members. For example, the EWB was founded at the nearby University of Colorado, Boulder campus in 2001, and has rapidly established numerous chapters throughout the country. One of our faculty members taught at the Federal University of Santa Maria (FUSM) in Brazil, and an adjunct faculty member is on the Board of Directors of the Namlo Foundation. Similar "word-of-mouth" connections provided entrée to all of the humanitarian organizations associated with the project. Other schools interested in establishing HE programs may find similar connections locally, or may seek additional opportunities through local churches, the Red Cross, or by searching the Internet.

\section{Logistics on international projects}

The health and safety of our students are paramount concerns in our plans. In a few instances, both senior design students and CSM freshmen and sophomore students in EPICS have participated in projects in materially disadvantaged regions of the world. (EPICS is Engineering Practices: Introductory Course Sequence, a required two course sequence in engineering design for CSM freshmen and sophomores.). For example, we recently financed travel for one senior design team that was designing and building a water treatment plant in St. Kitts and for a second team designing a church roof for a village in Mexico. In both cases, we have coordinated with the local government and sponsoring organizations to ensure that that our concerns for health and safety are met. In all service missions, we ascribe to a scrupulous regimen to ensure that the CSM students are not subjected to unwarranted risk for health or safety. Accordingly, our agreement with the Namlo Foundation calls for design and consultation only, since the site for 
these projects lies perilously close to the Tibetan border, and poses some risk at this time. Nevertheless, we have allocated a small fund in our travel budget for emergency evacuations. We consult the U.S. Department of State web page (http://travel.state.gov/travel_warnings.html) for updates on travel safety.

Students are instructed by senior design faculty and/or EWB representatives about health issues, such as the importance of clean water and appropriate hygiene. They are also required to show proof of all necessary inoculations, as advised by the regional Public Health Nurse. In addition, all CSM students are covered by health insurance. We insist that students refrain from purchasing drugs of any kind, and are prepared to send students back if they do not comply. The grant has a specific allocation for travel to service missions. Students are also advised to use money belts and to leave valuables at home, and to travel in pairs. We will also insist that all faculty advisors traveling with students to remote areas take Red Cross courses in first aid, and strongly encourage students to do the same.

\section{K-12 Outreach and Recruitment}

Although the Engineering program at CSM is exceptionally vigorous, our outreach activities are being designed to help us to diversify our enrollment, drawing students that have traditionally been uninterested in engineering. A 1990 study by Sue Rosser ${ }^{5}$ of pedagogical criteria for attracting and retaining more women in science has shown the importance of "social usefulness" in this endeavor. Consequently, we believe that an emphasis on service and on other humanitarian engineering projects, for example bioengineering for the handicapped, will be attractive to women and minority students, and enhance the standards of the program by drawing more applicants to the School. ${ }^{10}$

Our project contains a systemic program to arouse the interest of K-12 students and teachers for careers in engineering. For students, we plan a series of summer field sessions that integrate fun/sports activities with technical instruction. For example, one module will introduce the mathematics of ball motion (trajectories, gravity, golf ball roughness, stored energy, lift) during the morning session, with ball games during the afternoon session. Students will examine the effects of modifications to parameters of balls and ball acceleration, and surface roughness on ball kinematics. Another module will deal with water sports. Morning sessions will introduce the mathematical concepts of drag, buoyancy, and inertia, and these lessons will be followed by water sports in the afternoons. In another session, students will be introduced to the biophysical aspects of sports, such as swing, muscle strain, and effects of altitude. During the afternoon session, students will participate in gate lab studies to analyze, assess and improve their individual performance patterns.

These efforts are an extension of an existing K-12 activity held every summer at CSM, known as Robocamp (http://www.mines.edu/Outreach/Cont_Ed/courses/robo/home.htm), which challenges middle school students to create and compete with robots. The combination of fun, engineering design, hands-on construction, math skill development, and scientific method is irresistible to students. Although the robot projects usually focus on lunar exploration, applications to search and rescue scenarios may be equally compelling, and more relevant to the theme of humanitarian engineering.

For teachers, we plan a modified version of MEL, with emphasis on topics relevant to humanitarian engineering, such as: alternative energy systems (fuel cells, solar cells, wind 
turbine); sensors for measurement of contaminants; and design and fabrication of biomedical devices and measurement systems; micro-turbine design; desalinization; photovoltaic systems; alternative energy; biomechanics for the disabled; groundwater and pollutant transport and remediation; low-cost medical imaging methods; small-scale communications systems; remote sensing as a tool in community planning, infrastructure planning, natural resource planning, environmental assessment, and disaster relief. A course similar to this has already been offered by CSM faculty, with a small, but enthusiastic response by regional high school teachers.

We plan to involve both teachers and high school students in humanitarian engineering and community service activities where these are feasible and appropriate. Currently, one section of senior design completes the final implementation phase of the project during field session, a three-week session in early summer. This timing, corresponding with the beginning of summer vacation, is particularly advantageous for encouraging the participation of high school teachers and students. Thus, for example, a project involving the construction of playground facilities in the inner city could enlist the help of high school teachers and students. Through these activities, both the K-12 teachers and students will learn much more than technical skills. They will learn that engineering is a profession dedicated to the benefit of the community. We believe that this awareness will encourage more students to seriously consider careers in engineering.

Finally, we plan to develop a visual library, including videos, CD ROMs and photos, to illustrate community and international service projects for presentation in high schools, scout meetings, and similar venues. Our Humanitarian Engineering students will visit local mid and high schools where they will present information about Humanitarian Engineering, showing the videos and providing high school students and teachers with personal stories about working in this arena. These images will enable us to demonstrate the adventure and activism associated with Humanitarian Engineering to potential engineering students. In addition, the library of humanitarian engineering projects will be made available to professional societies such as ASEE and to recruiters and other engineering agencies upon request. The National Science, Technology and Mathematics Education Digital Library (http://www.ehr.nsf.gov/ehr/DUE/programs/nsdl/) is another venue for the HE library, and we will investigate the feasibility of posting our projects on this national resource.

\section{Problems and Perceptions}

The main difficulty that we have encountered in the implementation of the Humanitarian engineering program so far appears to be semantic. The program was originally named: Community Service Engineering. That phrase was meant to include both domestic and international community service. However, early interactions with students at CSM indicated that "Community Service" was perceived as having a mandatory connotation. This was confirmed by an informal study conducted with the students involved with the CSM chapter of Engineers Without Borders. Given that one of the main goals of the program is to enhance diversity at CSM by promoting a program that would motivate qualified high-school students to consider majoring in engineering, we decided to change the name of the program to "Humanitarian Engineering." There was some concern within the project team that the word "Humanitarian" might carry some historically negative connotation as well, but the informal survey described above showed that this was not an issue with the students. 
Various constituencies on campus voiced significant concerns regarding the use of "Humanitarian Engineering". A dialog was initiated to better understand these concerns and we found that the main concern originated from the perception that the establishment of a "Humanitarian Engineering" program might have a negative image impact on existing programs since they might then be seen as "non-Humanitarian" engineering. This showed us that we needed to clarify the goals of the project. It is critical to realize that what matters in this attempt to attract new constituencies to engineering is not how we, engineers, understand engineering contributions to Humanity at large, but the fact that high-school students who decide not to pick engineering as their college major, may do so on the basis of their perception of what is engineering. It is a fact that some consider engineering and technology to be a source of problems (e.g. pollution) rather than solution. Our goal is to change that view by emphasizing the humanitarian aspect of engineering endeavors. This view was communicated to other campus constituencies. We also made some efforts to better define what "humanitarian" means in documents used to set-up the program administratively. For example, the project team put together the following definition of Humanitarian Engineering Projects:

"Humanitarian engineering projects, usually operated on a non-profit basis, aim either to provide fundamental needs (like food, water, shelter, clothing) when these are missing or inadequate, or higher-level needs for underserved communities. Effective humanitarian projects seek full participation from the communities involved, in order to appropriately define the community's needs and the most desirable approach to meet those needs. The long-term perspective of humanitarian work highlights the importance of employing engineering strategies, designs, and technologies that promote the sustainability of both natural and human systems."

With very few exceptions, this clarification was helpful in garnering campus-wide support for the program.

\section{Acknowledgment}

The contribution of Humanitarian Engineering project team members to this paper and the support of the William and Flora Hewlett Foundation are gratefully acknowledged.

\section{Bibliography}

1. Bonasso Samuel, G. (2001). "Engineering, leadership, and integral philosophy." Journal of Professional Issues in Engineering Education and Practice, 127(1): 17-25.

2. Droste, R. L. (1997). Theory and Practice of Water and Wastewater Treatment._John Wiley \& Sons, Inc. New York.

3. Duffield James, F. and H. McCuen Richard (2000). "Ethical maturity and successful leadership." Journal of Professional Issues in Engineering Education and Practice 126(2): 79-82.

4. Florman, Samueal C. (1996), The Introspective Engineer, St. Martin's Press; ISBN: 031213987X; 1st edition (January 15, 1996)

5. Loftus, M. (2003). “A New Era,” ASEE Prism online, 12(8), April, 2003. 
6. Lyons William, C. (2000). "U.S. and international engineering education: A vision of engineering's future." Journal of Professional Issues in Engineering Education and Practice, 126(4): 152-155.

7. McCuen Richard, H. (1999). "Course on engineering leadership." Journal of Professional Issues in Engineering Education and Practice, 125(3): 79-82.

8. McIsaac Gregory, F. and C. Morey Nancy (1998). "Engineers' role in sustainable development: Considering cultural dynamics." Journal of Professional Issues in Engineering Education and Practice, 124(4): 110-119.

9. National Science Foundation (NSF), Science and Technology: Public Attitudes and Public Understanding, Science and Technology Indicators 2002, http://www.nsf.gov/search97cgi/vtopic.

10. Parsons Laura, Brigitte (1996). "Engineering in context: Engineering in developing countries." Journal of Professional Issues in Engineering Education and Practice, 122(4): 170-176.

\section{Biographical Information}

\section{JOAN GOSINK}

Dr. Joan Gosink is a Professor Emerita and Former Director of the Engineering Division at CSM, the largest department or division in the School, since 1991. Under her direction, the Division received various accolades, including designation as a Program of Excellence from the Colorado Commission on Higher Education. Dr. Gosink twice served as a Program Director at NSF. Among other strengths, Dr. Gosink is an experienced ABET evaluator, bringing unique insights on the ABET evaluation process to the project team.

\section{JEAN-PIERRE DELPLANQUE}

Dr. Jean-Pierre Delplanque is an Associate Professor in the Engineering Division at CSM. His research interests focus on theoretical and computational fluid dynamics and transport phenomena in inert and reactive multiphase flow with applications in combustion and materials processing. He has an Engineering Diploma from ENSEEIHT (Toulouse, France), an M.S. ("DEA") in Mechanics from the National Polytechnic Institute of Toulouse (France), and an M.S. and Ph.D. in Mechanical and Aerospace Engineering from UC Irvine.

\section{JUAN LUCENA}

Juan Lucena is Director of the McBride Honors Program in Public Affairs for Engineers and Associate Professor at the Liberal Arts and International Studies Division (LAIS) at the Colorado School of Mines. Currently, he is researching how images of globalization shape engineering education, hiring practices, and engineering practices and designs under a NSF CAREER Award titled Global Engineers: An Ethnography of Globalization in the Education, Hiring Practices and Designs of Engineers in Europe, Latin America, and the U.S. 